\title{
Evaluation of the Effects of Conflict Resolution, Peace Education and Peer Mediation: A Meta-Analysis Study
}

\author{
Fulya Turk ${ }^{1}$ \\ ${ }^{1}$ Department of Psychological Counseling and Guidance, Faculty of Education, Gaziantep University, Turkey \\ Correspondence: Fulya Turk, Department of Psychological Counseling and Guidance, Faculty of Education, \\ Gaziantep University, Gaziantep, Turkey. Tel: 90-342-360-4372. E-mail: fulyaturk@gantep.edu.tr
}

Received: August 16, 2017

doi:10.5539/ies.v11n1p25
Accepted: November 7, 2017 Online Published: December 22, 2017

URL: https://doi.org/10.5539/ies.v11n1p25

\begin{abstract}
The purpose of this study was to examine the effects of conflict resolution, peace education and peer mediation on the conflict resolution skills of students via meta-analysis method. 23 studies were determined to be in accordance with the study criteria. According to research findings conflict resolution, peace education and peer mediation education programs have a wide range of effect on the conflict resolution skills of students. In addition, the education program, education level, the type of application, publication type, the duration of application have been examined and evaluated. As a result, it can be stated that conflict resolution, peace education or peer mediation is effective in the constructive development of conflict resolution skills of the students.
\end{abstract}

Keywords: conflict resolution, peace education and peer mediation, school violence, meta-analyses

\section{Introduction}

Violent incidents at schools have adverse effects on the physical and psychological health of students while also preventing the perception of schools as safe locations and hindering the education process. Hence, it is a topic that concerns the society as a whole. Perceptions and opinions regarding the increase in violent incidents at schools both in our country and in the world result in an increased attention to this issue. Öğ̈̈lmüş (2006) compared the results of two studies on violence at schools thus putting forth an increase in school based violent incidents. The research commission of the Grand National Assembly of Turkey (2007) puts forth striking results regarding violence at schools. As a result of the study carried out, students put forth that they have been subject to violence during the past three months $55.7 \%$ of which was physical, $31.9 \%$ verbal, $36.3 \%$ emotional and $15.8 \%$ sexual. When asked who the individual inflicting the violence was, friends came out as the response with the highest ratio. These striking results indicate the extensiveness and frequency of violence at schools while putting forth that violence is an issue that should be emphasized. In yet another study, Bulut (2008) examined violence incidents from students to students in publications between the years of 2001-2006 and determined 302 incidents. It can also be observed in this study that violence occurs mostly inside the school and in the classroom, that violence takes place mostly during school dismissal and recess times and that the reasons for violence are discussion, swearing and hitting. Of the violence incidents, 53\% ended up in hospitals. Aküzüm and Oral (2015) carried out a study in which they determined according to the opinions of administrators and teachers that the most frequently observed violence incidents take place from student to student, that physical violence, verbal violence, peer bullying and abusing the opposite sex are among the more frequently observed themes of violence. It has been put forth as a result of the evaluation of violence incidents in press by Teyfur (2014) that there has been an increase in news on abuse, stabbing and drugs at schools. Another striking report (PISA, 2015) put forth the well-being status of children at the age of 15 in 72 countries. Accordingly, sense of school belonging is low for students in Turkey. In addition, $19 \%$ of the students in Turkey state that they are subject to peer bullying at school at least several times a month. The results of these studies indicate that violence incidents at schools should be evaluated in a multi-dimensional manner and that the required interventions should be made.

Interpersonal conflicts are natural and inevitable in any given school environment since there are many different people from different purpose, desire, value, relief and personal features. Studies indicate that student's conflict with others in classroom, playground, school bus or during playing and trying to solve these conflicts using 
verbal and physical violence (Bemak \& Keys, 2000; W. Johnson \& T. Johnson, 1995; W. Johnson \& R. Johnson, 2001; Taştan, 2004). There are three main source of conflict. Limited sources, lack of satisfaction of basic psychological needs and different values. Limited sources are money, time and asset related and generally easy to solve. According to Glasser psychological needs (being part of something, freedom, power and entertainment) can be the source of conflict. Different values contain different beliefs, cultural differences, attitudes, opinions and prejudices. These conflicts are not easy to deal with and only solved with awareness, respect and tolerance (Schrumpf, Crawford, \& Bodine, 2007).

School is crucially important for student to acquire core life skills. Students claim responsibility for their actions when they solve conflicts with their own skills (Smith, Daunic, Miller, \& Robinson, 2002). Conflict resolution skills also help students to gain empathy, effective communication, anger management and problem solving skills (Lane-Garon, 2000). Conflict resolution skills provide opportunity to learn living together and embrace diversity (Droisy \& Gaudron, 2003). When students do not have conflict resolution skills, teachers waste most of their time with student conflicts and school is perceived unsafe by students (Hart \& Gunty, 1997).

According to Breunlin, Cimmarusti, Bryant-Edwrads, and Hetherington (2002), school administrators use one of the three approaches for preventing violence at schools. The first approach is security. Security approach keeps violence fixed. The second approach is punishment. This approach gives the message that violence will not be tolerated. Whereas the third approach is school based prevention programs. School based prevention programs provide alternative methods for decreasing violence. School based prevention programs aim to provide students with constructive skills that will enable them to solve interpersonal conflicts without resorting to violence. Therefore, school based prevention programs make up majority of the studies for preventing violence. These programs provide a safe and constructive learning environment, support the social and emotional developments of the students and assist in creating an environment where conflicts can be resolved by constructive means in addition to decreasing and/or preventing violence (Jones, 2004). Conflict resolution education (CRE), peace education (PE) and peer mediation education (PM) are the primary school based prevention programs.

Conflict resolution education "models and teaches, in culturally meaningful ways, a variety of processes, practices and skills that help address individual, interpersonal, and institutional conflicts, and create safe and welcoming communities" (Association for Conflict Resolution, 2002, p. 1). Conflict resolution education programs provide students with a basic understanding of the nature of conflict, the dynamics of power and influence that operate in conflict, and the role of culture in how we see and respond to conflict (Jones, 2004).

Conflict resolution education is important to: individuals, to build competence in life skills; schools, classrooms, and school communities, to support effective and safe learning environments; and society, to ensure a functioning and peaceful democracy (Association for Conflict Resolution, 2002, p. 1).

According to Johnson and Johnson (2006), peace education is a type of education providing knowledge, skills, attitudes and values that enable the establishment of harmonious relations and the resolution of conflicts in a constructive manner. According to Sommers (2003), peace education helps develop communication skills of active listening and assertive speech, problem-solving skills of brainstorming or consensus building, and orientation skills of cultural awareness and empathy. Through peace education, students can recognize self-understanding and management in addition to external factors as domains of their influence on peace development. They learn that interpersonal and environmental circumstances are outcomes of interaction with internal and external processes. The pervasiveness of conflict topics in each school subject, as well as during interactions at school, provides a broad context for peace education (Carter, 2008).

Mediation is the process of helping two or more people to resolve their conflicts in a constructive manner carried out by an unbiased third party. Mediation is one step ahead of negotiation process and is the sum of all strategies that make negotiations more effective and efficient (Johnson and Johnson, 1995). When this process is carried out by a peer at school, it is called peer mediation. Peer mediation is a process that helps students to resolve their conflicts in a constructive and peaceful manner while supporting their social and emotional developments (Türnüklü, 2006, p. 70). These programs provide a unique opportunity for diverse students to use communication, human relations, and problem-solving skills in real-life settings. Effective programs can help to create a safe and welcoming school environment, improve interpersonal and inter-group relations, and assist in reducing school conflicts and violence, especially when part of a comprehensive violence prevention plan (Association for Conflict Resolution, 2007, p. 2). Peer mediation is the oldest and most common CRE intervention (Cohen, 2003; Schrumpf, Crawford, \& Bodine, 2007).

CRE and peace education are similar in terms of basic motivations, goals, key skills, and content. Yet CRE is domestically applied and peace education is internationally applied, and peace education has a stronger emphasis 
on social justice orientations and larger systemic issues of violence than conflict education programs (Jones, 2004). Also currently, CRE programs typically fit one of three delivery formats: direct skills instruction, peer mediation, or embedded curriculum. Peer mediation programs train a subgroup (sometimes called a cadre) of students in CRE specifically to assist other students to resolve disputes using a prescribed process (Garrard \& Lipsey, 2007). In other words, peer mediation is a type of conflict resolution education in which the emphasis is on providing mediation skills.

It has been observed in our country especially starting from the 2000's that many education programs have been adopted/developed and have been subject to effectiveness examinations for preventing behaviors such as violence, aggression and bullying at primary, secondary and high school levels (Sağkal, 2015). Both scientific studies and application studies have gained pace with an increase in the interest and emphasis on violence at schools. It has been observed as a necessity to popularize educations such as conflict resolution, peace education and peer mediation at schools within the scope of the Strategy and Action Plan for Preventing and Decreasing Violence at Educational Environments (2006-2011+). In parallel, this topic is also observed to gain emphasis in scientific studies. Indeed, it has been put forth by Türk and Cihangiroğlu (2017) that CRE and PM trainings are among the most frequently studied topics in graduate theses in the field of psychological counseling and guidance. It is thought that putting forth the effects via meta-analysis of this issue that attracts attention while providing information regarding the solution of a serious problem is an important issue. There is no meta-analysis study in our country that puts forth the effects of CRE, PE and PM trainings. In addition, six studies have been determined as a result of a literature survey that examines the effects of CRE, PE and PM trainings. W. Johnson and R. Johnson (2001) carried out a meta-analysis study in two countries, 8 different schools for 17 studies in which they examined the effects of only their own program entitled "Teaching to Be Peacemakers". Kmitta (1997) examined the effects of three different programs within a period of three years using only eight research studies. Wilson and Derzon (2003) and Wilson, Mark and Lipsey (2007) examined the effects of violence prevention programs on aggression via meta-analysis method. However, cr and pm make up only a small part of this study since the effects of all intervention programs have been examined in these studies. Burrell, Zirbel, and Allen (2003) carried out a study in which they performed a meta-analytic study using the mediation forms including the results of peer mediation applications. Finally, Jones and Kmitta (2000) carried out a comprehensive review study regarding the studies in the field of conflict resolution and they have also used the meta-analysis method in this study. Finally, it is thought that the examination via meta-analysis method of the effects of CRE, PE and PM trainings carried out at schools for preventing violence will shed light to new studies in this field and will give new ideas for future studies.

\section{Method}

Meta-analysis method was used in this study for determining the effects of conflict resolution, peace education and peer mediation education on the conflict resolution skills of students. Meta-analysis is comprised of statistical analyses used for integrating the multiple analysis results acquired from individual studies (Glass, 1976). In short, meta-analysis is the analysis of other analyses. It combines the results of other studies in a consistent and harmonious manner (Cohen, 1988). Meta-analysis is the grouping of similar studies on a certain topic, theme or field of study under certain criteria and the interpretation of the quantitative results of these studies (Dinçer, 2014, p. 4). De Coster (2004) defines it as a statistical method for the qualitative and quantitative combination of the results of studies carried out at different locations and times and different centers (Cit.: Kınay, 2012). In meta-analysis, the results acquired from small-scale individual studies carried out at different locations and times are combined thus reaching quantitatively more accurate results with an enlarged sample group (Çelebi Yıldız, 2002, Cit.: Kınay, 2012). The difference of meta-analysis from other literature survey methods is that it bases the combination, integration and analysis of different research results on statistical methods (Durlak, 1995). The stages followed in this study are as follows:

\subsection{Determination of the Study Objective and Problem}

The question to be researched in meta-analysis should be determined beforehand and the studies to be included in this analysis should be selected based on these criteria (Kang et al., 2000, Cit: Küçükönder, 2007). The objective of this study was to examine the effects of conflict resolution, peace education and peer mediation educations on the conflict resolution skills of students via meta-analysis method. For this purpose, studies have been examined which examine the effects of conflict resolution, peace education and peer mediation educations on conflict resolution skills in Turkey which have been carried out at primary education institutions, high schools and universities with semi-experimental and experimental patterns. Answers to the following sub-questions were sought for in the study: 
1) What is the level of effect of conflict resolution, peace education and peer mediation educations on the conflict resolution skills of students?

2) Is there a statistically significant difference between the effect sizes according to the education program used during the application process?

3) Is there a statistically significant difference between the effect sizes of the studies according to the education level at which the application is carried out?

4) Is there a statistically significant difference between the effect sizes of the studies according to the publication type (thesis, article)?

5) Is there a statistically significant difference between the effect sizes of the studies according to the duration of the application?

6) Is there a statistically significant difference between the effect sizes of the studies according to the type of the application (with selected students or to all students as class based)?

\subsection{Literature Survey}

A comprehensive literature survey was first carried out following the determination of the study question. In this scope, a query was made in the ULAKBIM, Google Academic and YOK thesis scan pages with concepts of "conflict resolution, peace education, mediation, peer mediation". A total of about 320 studies were reached as a result of this literature survey. Elimination was made according to study criteria following the survey.

\subsection{Inclusion Criteria}

Determining the study criteria was the most critical point of meta-analysis. These criteria determine which studies will be included in the analysis and which will be excluded (Dinçer, 2014, p. 40). The criteria determined for included studies have critical importance for understanding the scope of meta-analysis. The quality of the studies may be low if the inclusion criteria are very comprehensive resulting in decreased reliability. Whereas results may be acquired from only several studies and it may not be generalized if the criteria are too strict (Lam \& Kenedy, 2005).

Studies obtained as a result of the literature survey in accordance with the study objective were evaluated according to the following criteria:

a) That the study has been carried out in Turkey,

b) That a semi-experimental or experimental pattern has been used in the study,

c) That the independent variable of the study is either conflict resolution, peace education or peer mediation education,

d) That one of the dependent variables of the study is conflict resolution skills,

e) That the study has a control group,

f) That the average and standard deviation values related with the number of individuals in the experiment and control groups of the study as well as the conflict resolution skills have been provided in the study.

According to the criteria provided in the study, studies that were not using a semi-experimental or experimental pattern were excluded. A total of 270 studies were excluded. Afterwards, studies were excluded which did not include conflict resolution skills as a dependent variable. Accordingly, 15 studies met the inclusion criteria. Two studies that did not have a control group were not included. Finally, four studies were excluded which did not include the average and standard deviation values for conflict resolution skills. Similarly, 3 more studies were excluded since the measurement tool used was not a scale. Finally, studies with methodological problems among the three problems were not included. Because, studies with serious methodological issues are left out of the meta-analysis and the effect sizes are calculated for each study. While the independence of the data is protected in this manner, equal weights of the included studies are also provided (Bangert-Drowns \& Rudner, 1991; Cit.: Kansizoğlu, 2017). As a result, 23 studies were determined to be in accordance with the study criteria.

\subsection{Coding of the Studies and Ensuring the Validity and Reliability of the Coding Process}

A form was developed by the researcher for coding the studies. The developed form was presented to the opinions of experts in the field. The form was revised afterwards according to the feedback from the experts. The coding process used in the study was comprised of three stages. Information regarding the studies was given in the first section. In this scope, the study number, author/authors, year of publication and type of publication were included. Information on the content of the study was provided in the second section. Within this framework, 
education type (peace education, conflict resolution or peer mediation), study group (primary school, high school, and university), study pattern, follow up study, number of sessions and their durations were included. Whereas coding was performed in the final section by providing the numbers, averages and standard deviation values of the study data.

First of all, all studies were filed as a folder in the form of an electronic file with PDF extension. Afterwards, each study was listed in a Microsoft Excel sheet according to the names of the authors and the study numbers. The author names and files with PDF extension were linked via commands. Therefore, the required connection was provided for acquiring the desired information during the coding process. Whereas in the third stage of coding, the study numbers and the author names along with data regarding the study groups, average and standard deviation values were included in a separate Microsoft Excel study sheet thus completing the coding process. First, the researcher made the coding during the data coding process. Afterwards, another rater carried out the coding. Cohen Kappa coefficient (Cohen's $\kappa$ ) was used for evaluating the level of agreement between the two different raters. The basic feature of Cohen's $\mathrm{j}$ is to consider two raters as alternative forms of a test, and their ratings are analogous to the scores obtained from the test. Well known as a chance corrected measure of inter-rater reliability, Cohen's $j$ determines whether the degree of agreement between two raters is higher than would be expected by chance (Cohen 1960; Cit: Sun, 2011). When used and interpreted properly, the Kappa coefficient provides information for reliability determination as well as for other analyses. Kappa coefficient corrects the chance dependent section of the agreement thereby providing the real level of agreement (Sim and Wright, 2005; Cit.: Kansızoğlu, 2017). The coefficient of agreement for the two raters was determined as 0,86 in this study. This value is observed to be in a very good value interval (Cohen, 1968). The descriptive properties of the studies included have been given in Table 1.

Table 1. Descriptive Properties of the Included Studies

\begin{tabular}{|c|c|c|c|c|c|c|c|c|c|c|c|c|}
\hline Author & $\begin{array}{l}\text { Yea } \\
\mathrm{r}\end{array}$ & $\begin{array}{l}\text { Study } \\
\text { Type }\end{array}$ & $\begin{array}{l}\text { Stud } \\
\text { y } \\
\text { Gro } \\
\text { up } \\
\end{array}$ & Study Pattern & $\begin{array}{l}\text { Applicat } \\
\text { ion Type }\end{array}$ & $\begin{array}{l}\text { Applicat } \\
\text { ion } \\
\text { Period }\end{array}$ & $\begin{array}{l}\text { Educati } \\
\text { on } \\
\text { Level }\end{array}$ & $\begin{array}{l}\text { Numb } \\
\text { er of } \\
\text { Sessio } \\
\text { ns } \\
\end{array}$ & $\begin{array}{l}\text { Session } \\
\text { Duration }\end{array}$ & $\begin{array}{l}\text { Calcula } \\
\text { ted } \\
\text { Duratio } \\
\text { ns } \\
\end{array}$ & $\begin{array}{l}\text { Follo } \\
\text { w up } \\
\text { Test }\end{array}$ & $\begin{array}{l}\text { Place } \\
\text { bo } \\
\text { group }\end{array}$ \\
\hline $\begin{array}{l}\text { Arslan } \\
\text { E. }\end{array}$ & $\begin{array}{l}201 \\
4\end{array}$ & Master & 22 & $\begin{array}{l}\text { Experimental } \\
\text { pattern }\end{array}$ & $\begin{array}{l}\text { Peer } \\
\text { mediatio } \\
\mathrm{n}\end{array}$ & $\begin{array}{l}2013-20 \\
14\end{array}$ & $\begin{array}{l}7^{\text {th }} \\
\text { grade }\end{array}$ & 10 & $40 \mathrm{~min}$. & 10 & Yes & N/A \\
\hline Ateş, N. & $\begin{array}{l}201 \\
4\end{array}$ & Master & 30 & $\begin{array}{l}\text { Experimental } \\
\text { pattern }\end{array}$ & $\begin{array}{l}\text { Conflict } \\
\text { resolutio } \\
\mathrm{n} \\
\text { educatio } \\
\mathrm{n}\end{array}$ & $\begin{array}{l}2013-20 \\
14\end{array}$ & $\begin{array}{l}6^{\text {th }} \\
\text { grade }\end{array}$ & 7 & $50 \mathrm{~min}$. & 8 & Yes & N/A \\
\hline $\begin{array}{l}\text { Coşkun } \\
\text { er, E. }\end{array}$ & $\begin{array}{l}200 \\
8\end{array}$ & Master & 104 & $\begin{array}{l}\text { Semi-experim } \\
\text { ental pattern }\end{array}$ & $\begin{array}{l}\text { Peace } \\
\text { educatio } \\
\mathrm{n}\end{array}$ & $\begin{array}{l}2007-20 \\
08\end{array}$ & $\begin{array}{l}5^{\text {th }} \\
\text { grade }\end{array}$ & 32 & $40 \mathrm{~min}$. & 32 & N/A & N/A \\
\hline $\begin{array}{l}\text { Çiçekoğ } \\
\text { lu, P. }\end{array}$ & $\begin{array}{l}201 \\
4\end{array}$ & $\begin{array}{l}\text { Doctor } \\
\text { ate }\end{array}$ & 80 & $\begin{array}{l}\text { Experimental } \\
\text { pattern }\end{array}$ & $\begin{array}{l}\text { Conflict } \\
\text { resolutio } \\
\mathrm{n} \\
\text { educatio } \\
\mathrm{n}\end{array}$ & $\begin{array}{l}2013-20 \\
14\end{array}$ & $\begin{array}{l}13-17 \\
\text { ages }\end{array}$ & 10 & $50 \mathrm{~min}$. & 12,5 & Yes & N/A \\
\hline $\begin{array}{l}\text { Çavuş } \\
\text { Kaşık, } \\
\text { N. }\end{array}$ & $\begin{array}{l}201 \\
2\end{array}$ & Master & 20 & $\begin{array}{l}\text { Experimental } \\
\text { pattern }\end{array}$ & $\begin{array}{l}\text { Conflict } \\
\text { resolutio } \\
\mathrm{n} \text { and } \\
\text { peer } \\
\text { mediatio } \\
\mathrm{n}\end{array}$ & $\begin{array}{l}2010-20 \\
11\end{array}$ & $\begin{array}{l}7^{\text {th }} \\
\text { grade }\end{array}$ & 13 & $90 \mathrm{~min}$. & 29 & N/A & N/A \\
\hline $\begin{array}{l}\text { Damirc } \\
\text { hi ve } \\
\text { Bilge }\end{array}$ & $\begin{array}{l}201 \\
4\end{array}$ & Article & 70 & $\begin{array}{l}\text { Experimental } \\
\text { pattern }\end{array}$ & $\begin{array}{l}\text { Peace } \\
\text { educatio } \\
\mathrm{n}\end{array}$ & $\begin{array}{l}2013-20 \\
14\end{array}$ & $\begin{array}{l}7^{\text {th }} \\
\text { grade }\end{array}$ & 12 & $60 \mathrm{~min}$. & 18 & Yes & N/A \\
\hline
\end{tabular}




\begin{tabular}{|c|c|c|c|c|c|c|c|c|c|c|c|c|}
\hline Ergül H. & $\begin{array}{l}200 \\
8\end{array}$ & Master & 482 & $\begin{array}{l}\text { Semi-experim } \\
\text { ental pattern }\end{array}$ & $\begin{array}{l}\text { Negotiat } \\
\text { ion and } \\
\text { mediatio } \\
\mathrm{n}\end{array}$ & $\begin{array}{l}2006-20 \\
07\end{array}$ & $\begin{array}{l}9^{\text {th }} \\
\text { grade }\end{array}$ & 32 & $40 \mathrm{~min}$. & 32 & N/A & N/A \\
\hline $\begin{array}{l}\text { Gülkok } \\
\text { an, Y. }\end{array}$ & $\begin{array}{l}201 \\
1\end{array}$ & Master & 131 & $\begin{array}{l}\text { Semi-experim } \\
\text { ental pattern }\end{array}$ & $\begin{array}{l}\text { Peer } \\
\text { mediatio } \\
\mathrm{n} \\
\text { educatio } \\
\mathrm{n}\end{array}$ & $\begin{array}{l}2010-20 \\
11\end{array}$ & $\begin{array}{l}5^{\text {th }} \\
\text { grade }\end{array}$ & 32 & $40 \mathrm{~min}$. & 32 & N/A & N/A \\
\hline $\begin{array}{l}\text { Gündoğ } \\
\text { du, R. }\end{array}$ & $\begin{array}{l}200 \\
9\end{array}$ & $\begin{array}{l}\text { Doctor } \\
\text { ate }\end{array}$ & 43 & $\begin{array}{l}\text { Semi-experim } \\
\text { ental pattern }\end{array}$ & $\begin{array}{l}\text { Conflict } \\
\text { resolutio } \\
\mathrm{n}\end{array}$ & $\begin{array}{l}2008-20 \\
09\end{array}$ & $\begin{array}{l}9^{\text {th }} \\
\text { grade }\end{array}$ & 14 & $90 \mathrm{~min}$. & 31,5 & Yes & Yes \\
\hline $\begin{array}{l}\text { Kaya, } \\
\text { B. }\end{array}$ & $\begin{array}{l}201 \\
3\end{array}$ & Master & 161 & $\begin{array}{l}\text { Semi-experim } \\
\text { ental pattern }\end{array}$ & $\begin{array}{l}\text { Peace } \\
\text { educatio } \\
\mathrm{n}\end{array}$ & $\begin{array}{l}2010-20 \\
11\end{array}$ & $\begin{array}{l}4^{\text {th }} \\
\text { grade }\end{array}$ & 28 & $40 \mathrm{~min}$. & 28 & N/A & N/A \\
\hline Kuş, M. & $\begin{array}{l}200 \\
7\end{array}$ & Master & 30 & $\begin{array}{l}\text { Experimental } \\
\text { pattern }\end{array}$ & $\begin{array}{l}\text { Conflict } \\
\text { resolutio } \\
\mathrm{n}\end{array}$ & & $\begin{array}{l}9^{\text {th }} \text { and } \\
10^{\text {th }} \\
\text { grades }\end{array}$ & 5 & $120 \mathrm{~min}$. & 15 & N/A & N/A \\
\hline $\begin{array}{l}\text { Kutlu, } \\
\text { A. }\end{array}$ & $\begin{array}{l}201 \\
6\end{array}$ & Master & 24 & $\begin{array}{l}\text { Semi-experim } \\
\text { ental pattern }\end{array}$ & $\begin{array}{l}\text { Conflict } \\
\text { resolutio } \\
\mathrm{n}\end{array}$ & $\begin{array}{l}2015-20 \\
16\end{array}$ & $\begin{array}{l}5,6,7,8^{\text {th }} \\
\text { grades }\end{array}$ & 10 & $60 \mathrm{~min}$. & 15 & N/A & N/A \\
\hline $\begin{array}{l}\text { Mutluo } \\
\text { ğlu ve } \\
\text { Serin }\end{array}$ & $\begin{array}{l}201 \\
2\end{array}$ & Article & 40 & $\begin{array}{l}\text { Semi-experim } \\
\text { ental pattern }\end{array}$ & $\begin{array}{l}\text { Conflict } \\
\text { resolutio } \\
\mathrm{n}\end{array}$ & & $\begin{array}{l}5^{\text {th }} \\
\text { grade }\end{array}$ & 6 & $\begin{array}{l}\text { Unspecif } \\
\text { ied }\end{array}$ & & N/A & N/A \\
\hline $\begin{array}{l}\text { Öner } \\
\text { Koruklu } \\
\text {, N. }\end{array}$ & $\begin{array}{l}200 \\
3\end{array}$ & $\begin{array}{l}\text { Doctor } \\
\text { ate }\end{array}$ & 60 & $\begin{array}{l}\text { Experimental } \\
\text { pattern }\end{array}$ & $\begin{array}{l}\text { Mediatio } \\
\mathrm{n} \\
\text { educatio } \\
\mathrm{n}\end{array}$ & $\begin{array}{l}2002-20 \\
03\end{array}$ & $\begin{array}{l}\text { Univers } \\
\text { ity }\end{array}$ & 10 & $160 \mathrm{~min}$. & 40 & N/A & N/A \\
\hline $\begin{array}{l}\text { Sünbül, } \\
\text { D. }\end{array}$ & $\begin{array}{l}200 \\
8\end{array}$ & Master & 482 & $\begin{array}{l}\text { Semi-experim } \\
\text { ental pattern }\end{array}$ & $\begin{array}{l}\text { Negotiat } \\
\text { ion and } \\
\text { mediatio } \\
\mathrm{n} \\
\text { educatio } \\
\mathrm{n}\end{array}$ & $\begin{array}{l}2006-20 \\
07\end{array}$ & $\begin{array}{l}9^{\text {th }} \\
\text { grade }\end{array}$ & 32 & $40 \mathrm{~min}$. & 32 & N/A & N/A \\
\hline $\begin{array}{l}\text { Şahin } \\
\text { Altun, } \\
\text { Ö. }\end{array}$ & $\begin{array}{l}201 \\
1\end{array}$ & $\begin{array}{l}\text { Doctor } \\
\text { ate }\end{array}$ & 105 & $\begin{array}{l}\text { Semi-experim } \\
\text { ental pattern }\end{array}$ & $\begin{array}{l}\text { Conflict } \\
\text { resolutio } \\
\mathrm{n}\end{array}$ & $\begin{array}{l}2010-20 \\
11\end{array}$ & $\begin{array}{l}\text { Univers } \\
\text { ity }\end{array}$ & 10 & $60 \mathrm{~min}$. & 15 & N/A & N/A \\
\hline $\begin{array}{l}\text { Şevkin, } \\
\text { B. }\end{array}$ & $\begin{array}{l}200 \\
8\end{array}$ & Master & 675 & $\begin{array}{l}\text { Semi-experim } \\
\text { ental pattern }\end{array}$ & $\begin{array}{l}\text { Negotiat } \\
\text { ion and } \\
\text { mediatio } \\
\mathrm{n}\end{array}$ & $\begin{array}{l}2006-20 \\
07\end{array}$ & $\begin{array}{l}4^{\text {th }} \text { and } \\
5^{\text {th }} \\
\text { grades }\end{array}$ & 32 & $40 \mathrm{~min}$. & 32 & N/A & N/A \\
\hline $\begin{array}{l}\text { Tapan, } \\
\text { Ç. }\end{array}$ & $\begin{array}{l}200 \\
6\end{array}$ & Master & 37 & $\begin{array}{l}\text { Semi-experim } \\
\text { ental pattern }\end{array}$ & $\begin{array}{l}\text { Peace } \\
\text { educatio } \\
n\end{array}$ & $\begin{array}{l}2005-20 \\
06\end{array}$ & $\begin{array}{l}8^{\text {th }} \\
\text { grade }\end{array}$ & 11 & $80 \mathrm{~min}$. & 24 & N/A & N/A \\
\hline $\begin{array}{l}\text { Taştan, } \\
\text { N. }\end{array}$ & $\begin{array}{l}200 \\
4\end{array}$ & $\begin{array}{l}\text { Doctor } \\
\text { ate }\end{array}$ & 68 & $\begin{array}{l}\text { Experimental } \\
\text { pattern }\end{array}$ & $\begin{array}{l}\text { Conflict } \\
\text { resolutio } \\
\mathrm{n} \quad \text { and } \\
\text { peer } \\
\text { mediatio } \\
\mathrm{n}\end{array}$ & & $\begin{array}{l}6^{\text {th }} \\
\text { grade }\end{array}$ & 8 & $80 \mathrm{~min}$. & 16 & Yes & Yes \\
\hline $\begin{array}{l}\text { Türk, F. } \\
1\end{array}$ & $\begin{array}{l}200 \\
8\end{array}$ & Master & 591 & $\begin{array}{l}\text { Semi-experim } \\
\text { ental pattern }\end{array}$ & $\begin{array}{l}\text { Negotiat } \\
\text { ion and } \\
\text { mediatio } \\
\mathrm{n}\end{array}$ & $\begin{array}{l}2006-20 \\
07\end{array}$ & $\begin{array}{l}4^{\text {th }} \text { and } \\
5^{\text {th }} \\
\text { Grades }\end{array}$ & 32 & $40 \mathrm{~min}$. & 32 & N/A & N/A \\
\hline
\end{tabular}




\begin{tabular}{|c|c|c|c|c|c|c|c|c|c|c|c|c|}
\hline $\begin{array}{l}\text { Türk,F. } \\
2\end{array}$ & $\begin{array}{l}201 \\
3\end{array}$ & $\begin{array}{l}\text { Doctor } \\
\text { ate }\end{array}$ & 57 & $\begin{array}{l}\text { Experimental } \\
\text { pattern }\end{array}$ & $\begin{array}{l}\text { Peer } \\
\text { mediatio } \\
\mathrm{n}\end{array}$ & $\begin{array}{l}2010-20 \\
11\end{array}$ & $\begin{array}{l}9^{\text {th }} \\
\text { grade }\end{array}$ & 20 & $45 \mathrm{~min}$. & 22,5 & N/A & N/A \\
\hline $\begin{array}{l}\text { Uysal, } \\
\text { Z. }\end{array}$ & $\begin{array}{l}200 \\
6\end{array}$ & Master & 30 & $\begin{array}{l}\text { Experimental } \\
\text { pattern }\end{array}$ & $\begin{array}{l}\text { Conflict } \\
\text { resolutio } \\
\mathrm{n}\end{array}$ & $\begin{array}{l}2005-20 \\
06\end{array}$ & $\begin{array}{l}9^{\text {th }} \\
\text { grade }\end{array}$ & 9 & $50 \mathrm{~min}$. & 11,2 & Yes & N/A \\
\hline $\begin{array}{l}\text { Zengin, } \\
\text { F. }\end{array}$ & $\begin{array}{l}200 \\
8\end{array}$ & Master & 591 & $\begin{array}{l}\text { Semi-experim } \\
\text { ental pattern }\end{array}$ & $\begin{array}{l}\text { Negotiat } \\
\text { ion and } \\
\text { mediatio } \\
\mathrm{n}\end{array}$ & $\begin{array}{l}2006-20 \\
07\end{array}$ & $\begin{array}{l}4^{\text {th }} \text { and } \\
5^{\text {th }} \\
\text { Grades }\end{array}$ & 32 & $40 \mathrm{~min}$. & 32 & N/A & N/A \\
\hline
\end{tabular}

When Table 1 is examined, it is observed that the included studies are all dated after the year 2000 despite the fact that a year criteria has not been implemented for the studies included in meta-analysis. The first study that was included in the meta-analysis was from 2003, whereas the last was from 2016. Highest number of publications on conflict resolution, peace education and peer mediation was made in $2008(26 \%, \mathrm{f}=6)$. The year with the second highest number of publications was $2014(17.3 \%, \mathrm{f}=4)$. There are two publications per year in the years 2006, 2011, 2012 and 2013. There is one study per year in the years 2003, 2004, 2007, 2009. When the publication type of the studies was examined, it was observed that $65.2 \%(\mathrm{~N}=15)$ of the studies included in the meta-analysis were master's degree theses. Whereas $21.7 \%(\mathrm{~N}=5)$ were doctorate thesis studies. The number of research articles was two $(\mathrm{f}=\%$ 8.6). At this point, we should emphasize one point. Same studies that were published as both graduate study thesis and as an article have been included in the literature survey of the study. Hence, it can be thought that the number or articles is lower. When the study groups in the studies are examined, the total number of individuals included in the applications/experimental process was 3933 . Whereas the number of individuals in the smallest study group was 20, the number of individuals in the largest study group was 675 resulting in an average number of people of 177. It is possible to indicate that majority of the studies included in the meta-analysis have been carried out with larger groups. When the research pattern of the studies included in the meta-analysis were examined, it can be observed that semi-experimental pattern has been used in 13 studies $(\mathrm{f}=56.5 \%)$ and that experimental pattern has been used in 10 studies $(\mathrm{f}=43.4 \%)$. When the educations applied during the experimental procedure process of the studies were examined; it was observed that peer mediation was applied in 11 studies ( $\mathrm{f}=47.8 \%)$, conflict resolution in eight $(\mathrm{f}=34.7 \%)$ and peace education in four ( $\mathrm{f}=$ $17.3 \%)$. Since the education has been named as conflict resolution and mediation in two studies, the content of the education was examined. Accordingly, coding was made to the mediation education since the education included mediation process and applications. Since, only conflict resolution education has been included in studies with conflict resolution education. Whereas, even though information has been provided on conflict resolution process in mediation educations, the main theme of the program would be to learn and apply the steps of mediation. When the education level of the groups included in the studies were examined, it was observed that 14 studies $(\mathrm{f}=60.8 \%)$ were carried out at a primary school, seven studies $(\mathrm{f}=30,4 \%)$ at a high school and two studies $(\mathrm{f}=8.6 \%)$ at a university. Accordingly, it can be observed that the primary education group is the most preferred group among the studies included in the meta-analysis. Studies carried out at the primary and secondary education levels have been taken into consideration under the title of primary education in this study. Because primary education was under discussion during the period when the study was carried out, there are studies carried out with both $4^{\text {th }}$ grade and $5^{\text {th }}$ grade students. When the number and durations of the sessions were examined as another descriptive property, it was observed that the number and durations of sessions varied significantly in the studies. The number and duration of the sessions were multiplied during the coding process in order to be able to carry out a common evaluation thus determining the education time and these education times were recalculated according to a 40 minute course. Accordingly, whereas the longest education time was 40 class course hours, the shortest education time was 8 course hours and the average education time of the studies included in the study was 23.6 course hours. Whereas follow-up measurement was made in seven ( $\mathrm{f}=$ $30.4 \%$ ) of the studies, follow-up measurement was not made in 16 studies $(\mathrm{f}=69.5 \%)$. Whereas placebo group is present in only two ( $\mathrm{f}=8.6 \%)$ studies, there is no placebo group in $21(\mathrm{f}=91.3 \%)$ studies.

\subsection{Calculation of Effect Sizes}

Effect size is the fundamental unit of a meta-analysis study and it is a value that reflects the magnitude of the relationship between two variables or the magnitude of the application effect. Effect sizes are calculated for each study. Following these measurements, the effect coefficient is used for determining the agreement between the studies as well as the general impact on the field (Borenstein et al., 2013). 
In this study, dates of 23 studies were combined via meta-analysis method for determining the effectiveness of conflict resolution, peace education and peer mediation educations. One of the dependent variables of the studies included in the meta-analysis has to be conflict resolution skills. The measurement tools used for the studies included in the research were Conflict Resolution Skills Scale developed by Sar1 (2005), Conflict Resolution Behavior Determination Scale developed by Koruklu (1998), Conflict Resolution Scale developed by Akbalık (2001) and the Conflict Resolution scale developed by McClellan (1997) which was adopted into Turkish by Taştan (2004).

Magnitudes of the study groups along with the averages and standard deviation values of the experiment and control groups were present for all studies included in the meta-analysis. In this study, Hedge $g$ effect size index which puts forth the corrected and standardized average difference among the groups has been preferred for calculating the effect size values of the studies included in the meta-analysis. The tendency to show the precise value more than necessary in small samples may result in a slight bias of $d$. At this stage, the index that is expressed as Hedge $g$ should be preferred in order for the estimation of Cohen $d$ to be unbiased (Borenstein et.al., 2013, p. 27).

MS Office Excel 2007 and Comprehensive Meta Analysis (CMA) software were used in the generation of the calculations, tables and graphs used in the results and interpretation sections of the study. Thalheimer and Cook (2002) effect size classification has been used in this study: Accordingly;

$0.15<$ effect size value acts at $<0.15$ insignificant level,

$0.15<$ effect size value at $<0.40$ small level,

$0.40<$ effect size value at $<0.75$ moderate level,

$0.75<$ effect size value at $<1.10$ wide level

$1.10<$ effect size value at $<1.45$ very wide level

and $1,45<$ effect size at perfect level.

\subsection{Validity and Publication Bias of the Study}

Publication bias is one of the most important validity problems in meta-analysis. Publication bias occurs when the bias that occurs in published literature due to the greater possibility of publication of studies with statistically significant results is carried over to the meta-analyses (Borenstein, Hedges, Higgins, \& Rothstein, 2013, p. 268; Üstün \& Eryllmaz, 2014). The effect sizes of the studies in meta-analysis may be greater than necessary for this purpose. Because meta-analysis studies represent a biased sample group in the target population (Borenstein et al., 2013). Funnel plot, Rosenthal's fail-safe N method and Orwin's reliable $\mathrm{N}$ method have been used in this study for publication bias.

Funnel plot is a method for putting forth the relationship between study size and effect size. The funnel diagram shoes the effect size on the X-axis, sample size or variance on the Y-axis. In case of publication bias, it is expected that the effect sizes of the studies will be collected symmetrically at the top, that they will be collected in the middle when some studies are missing and that they will be collected at a point very close to the bottom in case a large number of studies are missing (Borenstein et al., 2013, p. 273). The funnel plot for this study has been given in Figure 1: 


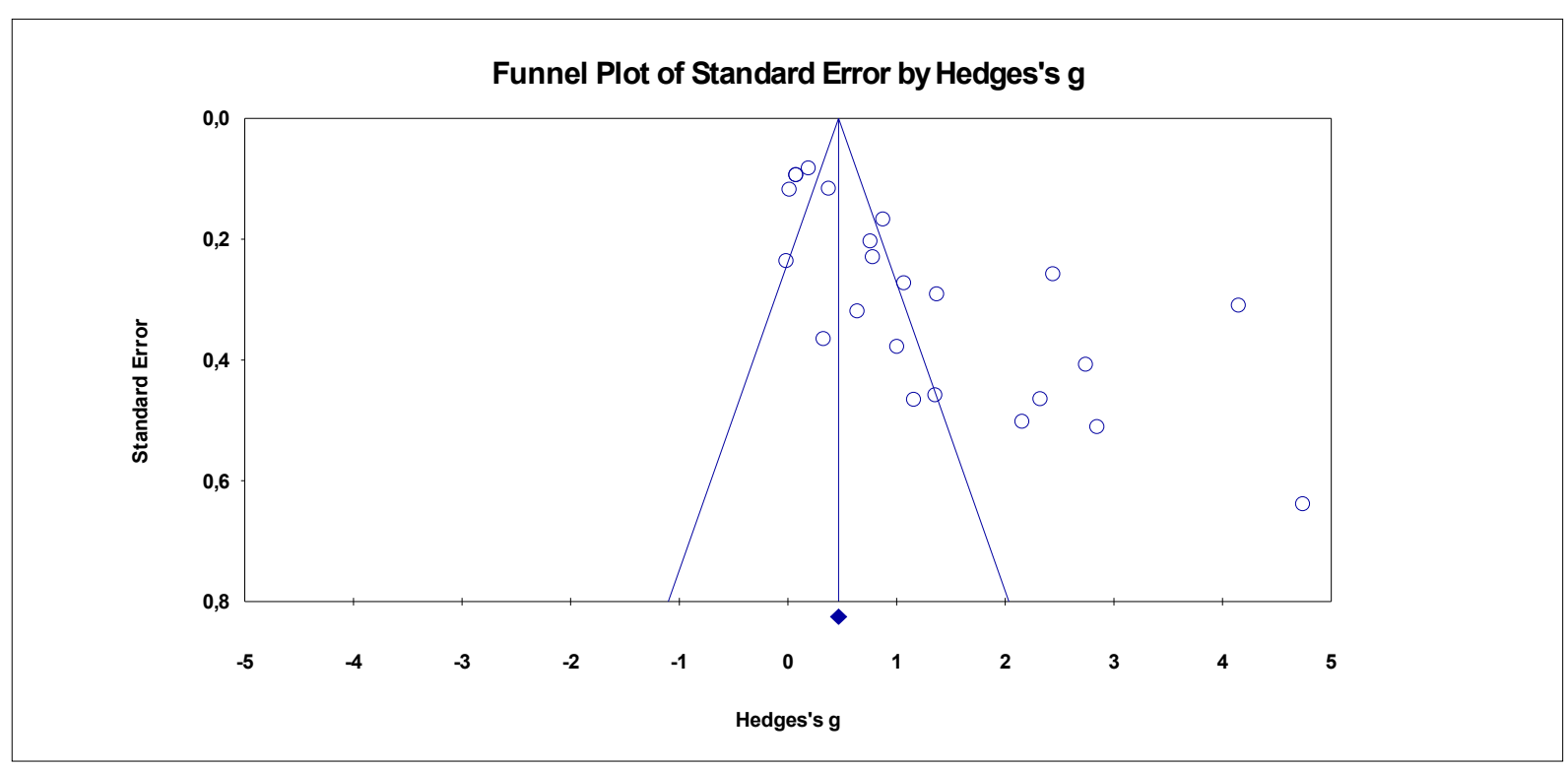

Figure 1. Funnel plot related to study bias

It can be observed when the graph is examined that the included studies are located in the middle and towards the right of the funnel plot and that they are slightly asymmetric. It is put forth here that the possibility of publication bias is increased with decreasing number of samples. Another factor is that studies with statistically significant results have a higher probability of being published in literature in comparison with studies that do not yield statistically significant results (Borenstein et al., 2013, p. 268). As can be seen, there is skewness towards the right in this funnel plot. This puts forth that only studies with statistically significant results have been included in the study. However, studies such as unpublished graduate theses have also been included in this research. As was put forth by Üstün and Eryılmaz (2014), file drawer problem meaning the publication of studies with only statistically significant lead to bias and this bias is carried over to the meta-analysis. It is very important to prevent publication bias by including both published and unpublished studies to the meta-analysis as the most effective means of protection from the adverse effects of publication bias. Nevertheless, inclusion of unpublished studies will not guarantee zero publication bias. That is why, methods developed for diagnosing and eliminating bias should be used in order to provide evidence regarding the fact that the meta-analysis results are sufficiently resistant against the inclusion of new studies with negative results (Üstün \& Eryılmaz, 2014). In addition, since the interpretation of funnel plots is strongly subjective (Borenstein et al., 2013, p. 273), it is best to make use of other methods.

Rosenthal's fail-safe $\mathrm{N}$ method can be defined as the number of new studies that should be included in the meta-analysis in order to "cancel out" the effect in meta-analysis (Borenstein et al., 2013, p. 274). Rosenthal argues that the results are resistant against publication bias if the FSN value is greater in comparison with the number of observed studies (Üstün \& Eryllmaz, 2014). The fail-safe N method results calculated in this study have been given in Table 2 .

Table 2. Rosenthal FSN results

\begin{tabular}{ll}
\hline Z-value for observed studies & 19.00064 \\
p-value for observed studies & 0.00000 \\
Alpha & 0.05 \\
Direction & 2 \\
Z value for Alpha & 1.95996 \\
Number of observed studies & 23 \\
FSN & 2139 \\
\hline
\end{tabular}

As can be seen in Table 2, the value calculated for 23 studies in the meta-analysis study examining the effects of conflict resolution, peace education and peer mediation education is 15,27 . This value is calculated as 15,27 using the $\mathrm{N} /(5 \mathrm{k}+10)$ formula and this value indicates that the results of the meta-analysis is sufficiently tolerant 
for future studies. It is concluded when the value of $\mathrm{N} /(5 \mathrm{k}+10)$ exceeds 1 that the meta-analysis results are sufficiently strong for future studies (Üstün \& Eryılmaz, 2014). The fact that the value in this study is quite higher than 1 is an indication that it is quite strong for similar studies that will be carried out in the future.

Finally, Orwin's fail-safe $\mathrm{N}$ formula was used in this study to determine publication bias. Different than Rosenthal's fail-safe N method, Orwin's fail-safe N method enables the calculation of the specific effect size that the general effect size magnitude will decrease to with the addition of lost studies in addition to the effect sizes of the lost studies (Üstün \& Eryılmaz, 2014). Table 3 shows the results of Orwin's fail-safe N method.

Table 3. Orwin's fail-safe N Calculations

\begin{tabular}{ll}
\hline Hedge's g for observed studies & 0.46531 \\
Criteria for "insignificant" Hedge g & 0.001 \\
Average Hedge g for lost studies & 0.000 \\
FSN & 1048 \\
\hline
\end{tabular}

As can be seen in Table 3, a total of 1048 additional studies with zero effect are required in order for the general effect size magnitude to decrease down to the 0,01 value that is selected as "insignificant". If the effect size values of the studies to be included are increased from zero to 0,05 , the number of studies to be included is 192 .

\subsection{Heterogeneity Test and the Meta-Analysis Model Used}

The most important premise of the constant-effect model is that there is only one actual effect size for all studies. This premise also means that the differences in the observed effects are due only to errors in sampling. On the other hand, random-effects model is based on the opinion that the actual effect size may vary from study to study due to ceratin intervening variables such as the ages of the participants, their education level or class size. Hence, actual effect size is distributed around certain averages (Üstün \& Eryllmaz, 2014). The model to be used should be determined in a meta-analysis study. Heterogeneity test is used for determining the model to be chosen. Constant effect model is used in case the results of individual studies turn out to be homogeneous as a result of the heterogeneity test, whereas random effects model is used in case the results are heterogeneous (Dinçer, 2014, p. 19). Table 4 shows the heterogeneity test results.

Table 4. Certain findings related with the heterogeneity test

\begin{tabular}{|c|c|c|c|c|c|c|}
\hline $\begin{array}{c}\text { Average Effect } \\
\text { Size }(\mathrm{g})\end{array}$ & $\begin{array}{c}\text { Degrees of } \\
\text { Freedom (df) }\end{array}$ & $\begin{array}{c}\text { Homogeneity } \\
\text { Value } \\
\text { (Q) }\end{array}$ & $\begin{array}{c}\text { Chi-Square Table } \\
\text { Value } \\
\left(\mathrm{X}^{2}\right)\end{array}$ & $\begin{array}{c}\text { Standard } \\
\text { Error } \\
(\mathrm{SE})\end{array}$ & $\mathrm{I}^{2}$ & $\begin{array}{c}95 \% \text { Reliability Interval for } \\
\text { Effect Size } \\
(\mathrm{ES} ; \% 95 \mathrm{cl})\end{array}$ \\
\hline 0.465 & 22 & 422.282 & 33.924 & 0.037 & 94.790 & 0.392 \\
\hline
\end{tabular}

When the analysis results given in Table 4 are examined, it can be observed that the $Q$ statistical value has been calculated as 422,282 . This value is much greater than the 33,924 critical value presumed for 22 degrees of freedom at a significance level of $95 \%$ for the chi-square $\left(X^{2}\right)$ table. In addition, $I^{2}$ coefficient is the actual heterogeneity ratio of the total change in the observed effect. This measurement is quite handy for the calculation of heterogeneity measurement since it is not sensitive to the number of studies and the measurement of effect size coefficients (Borenstein et al., 2013, p. 119). Higgins et al. (2003) suggested certain indefinite reference points for $\mathrm{I}^{2}$. They expressed these values as low, moderate and high with values of $25 \%, 50 \%$ and $75 \%$ (Cit.: Borenstein et al., 2013). In this study, the value of $\mathrm{I}^{2}$ has been calculated as 94,790. This means that; whereas $94.79 \%$ of the variance is the variance between the studies, $5 \%$ is the variance inherent to the study based on random error. It can be stated that the acquired $94.79 \%$ value has a high level of heterogeneity according to the classification by Higgins et.al. (2003). In addition, the value of $p$ as .000 is lower than the value of significance which is $p=.05$. All these values $\left(Q=422,282, p<.05, \mathrm{I}^{2}=94,790\right)$ indicate that there is a heterogeneous distribution among the effect sizes and that random effects model has to be used when interpreting the effect sizes.

\section{Results}

The findings acquired from the study have been answered in the light of the research questions which have been 
presented below.

1) What kind of an effect do conflict resolution, peace education and peer mediation educations have on the conflict resolution skills of students?

Effect sizes of individual studies along with other statistical results related with the general effect size have been given in Table 5.

Table 5. Effect sizes of individual studies and other statistics

\begin{tabular}{|c|c|c|c|c|c|c|c|}
\hline Study & Effect Size & Standard Error & Variance & $\begin{array}{c}\text { Lower } \\
\text { Limit }\end{array}$ & $\begin{array}{l}\text { Upper } \\
\text { Limit }\end{array}$ & z Value & $\mathrm{p}$ \\
\hline Arslan, E. & 1.357 & 0.458 & 0.210 & 0.458 & 2.255 & 2.960 & 0.003 \\
\hline Ateş, $\mathrm{N}$. & 2.324 & 0.465 & 0.216 & 1.413 & 3.236 & 4.998 & 0.000 \\
\hline Coşkuner, E. & 2.442 & 0.258 & 0.067 & 1.936 & 2.948 & 9.464 & 0.000 \\
\hline Çavuş Kaşık, N. & 1.161 & 0.466 & 0.217 & 0.248 & 2.074 & 2.491 & 0.013 \\
\hline Çiçekoğlu, P. & 0.782 & 0.230 & 0.053 & 0.331 & 1.233 & 3.402 & 0.001 \\
\hline Damirchi ve Bilge. & 0.014 & 0.236 & 0.056 & -0.477 & 0.450 & 0.058 & 0.954 \\
\hline Ergül, H. & 0.077 & 0.094 & 0.009 & -0.107 & 0.262 & 0.821 & 0.411 \\
\hline Gülkokan Y. & 4.150 & 0.310 & 0.096 & 3.543 & 4.758 & 13.385 & 0.000 \\
\hline Gündoğdu, R. & 0.329 & 0.365 & 0.134 & -0.387 & 1.046 & 0.901 & 0.368 \\
\hline Kaya, B. & 0.877 & 0.167 & 0.028 & 0.549 & 1.205 & 5.235 & 0.000 \\
\hline Kuş, M. & 1.006 & 0.378 & 0.143 & 0.265 & 1.747 & 2.659 & 0.008 \\
\hline Kutlu, A. & 2.158 & 0.502 & 0.252 & 1.173 & 3.143 & 4.296 & 0.000 \\
\hline Mutluoğlu ve Serin & 0.641 & 0.320 & 0.102 & 0.014 & 1.267 & 2.004 & 0.045 \\
\hline Öner Koruklu, N. & 1.070 & 0.273 & 0.074 & 0.535 & 1.605 & 3.920 & 0.000 \\
\hline Sünbül, D. & 0.077 & 0.094 & 0.009 & -0.107 & 0.262 & 0.821 & 0.411 \\
\hline Şahin Altun, Ö. & 0.760 & 0.204 & 0.042 & 0.360 & 1.159 & 3.726 & 0.000 \\
\hline Şevkin, B. & 0.015 & 0.118 & 0.014 & -0.216 & 0.246 & 0.127 & 0.899 \\
\hline Tapan, Ç. & 4.742 & 0.639 & 0.408 & 3.490 & 5.994 & 7.423 & 0.000 \\
\hline Taştan, N. & 2.743 & 0.408 & 0.166 & 1.944 & 3.543 & 6.724 & 0.000 \\
\hline Türk, F. 1 & 0.192 & 0.083 & 0.007 & 0.029 & 0.354 & 2.316 & 0.021 \\
\hline Türk, F. 2 & 1.373 & 0.292 & 0.085 & 0.801 & 1.944 & 4.708 & 0.000 \\
\hline Uysal, Z. & 2.848 & 0.511 & 0.261 & 1.846 & 3.850 & 5.570 & 0.000 \\
\hline Zengin, $\mathrm{F}$. & 0.376 & 0.117 & 0.014 & 0.148 & 0.605 & 3.228 & 0.001 \\
\hline General Effect Level & 1.256 & 0.179 & 0.032 & 0.906 & 1.606 & 7.029 & 0.000 \\
\hline
\end{tabular}

As can be seen in Table 5, the effect sizes of individual studies range between 0,014 and 4,742. The general effect size for the effect sizes of individual studies has been determined as 1,256 . According to the effect size classification by Thalheimer and Cook (2002), this interval is an indication that the effect is quite large.

2) Is there a statistically significant difference between the effect sizes according to the education program used in the application process?

Table 6 shows the findings related with whether the effect sizes of the studies differ at statistically significant levels according to whether conflict resolution, peace education and peer mediation educations have been given or not:

Table 6. Findings related with the effect size and heterogeneity test according to the education program used in the study

\begin{tabular}{|c|c|c|c|c|c|c|c|}
\hline \multicolumn{2}{|c|}{ Education Programs } & \multirow[b]{2}{*}{$\begin{array}{c}\text { Number of } \\
\text { Studies }\end{array}$} & \multicolumn{2}{|c|}{$95 \%$ Confidence Interval $(95 \% C I)$} & \multirow[t]{2}{*}{$\begin{array}{c}\text { Degrees of } \\
\text { Freedom }(d f)\end{array}$} & \multicolumn{2}{|c|}{ Heterogeneity Test } \\
\hline & Hedge $g$ & & Lower Limit & Upper Limit & & $Q$ Value & $p$ value \\
\hline Conflict Resolution & 1.253 & 8 & 0.740 & 1.765 & 2 & & \\
\hline Peace Education & 1.892 & 4 & 0.540 & 3.244 & & 1.460 & 0.482 \\
\hline Peer Mediation & 1.052 & 11 & 0.609 & 1.496 & & & \\
\hline
\end{tabular}


When Table 6 is examined, it can be observed that all effect sizes are in the positive direction, that the effect size values for studies in which peace education programs have been used are greater in comparison with the other education programs with a value of $g=1,892$. On the other hand, when it is considered whether the effect sizes obtained from primary studies differ at statistically significant levels according to the applied education programs or not, it was determined that the value of $Q=1,460$ is lower in comparison with the critical value of 5,991 determined in the $\mathrm{X}^{2}$ table at a $95 \%$ level of significance and degrees of freedom of 2 . The fact that the $Q$ value between the groups is lower than the critical value puts forth that the conflict resolution, peace education and peer mediation education programs do not differ at statistically significant levels with regard to their effect sizes.

3) Is there a statistically significant difference between the effect sizes of the studies according to the education level at which the application is carried out?

Findings have been given in Table 7 related with whether the effect sizes of the studies differ at statistically significant levels according to the education level at which the application is carried out:

Table 7. Effect size according to the education level at which the application has been carried out and the heterogeneity test

\begin{tabular}{|c|c|c|c|c|c|c|c|}
\hline \multicolumn{2}{|c|}{ Education Level } & \multirow[b]{2}{*}{$\begin{array}{c}\text { Number of } \\
\text { Studies }\end{array}$} & \multicolumn{2}{|c|}{95 Confidence Interval $(95 \% C I)$} & \multirow[t]{2}{*}{$(d f)$} & \multicolumn{2}{|c|}{ Heterogeneity Test } \\
\hline & Hedge $g$ & & Lower Limit & Upper Limit & & $Q$ Value & $p$ value \\
\hline Primary school & 1.564 & 14 & 1.005 & 2.123 & 2 & & \\
\hline High school & 0.782 & 7 & 0.335 & 1.230 & & 5.386 & 0.068 \\
\hline University & 0.871 & 2 & 0.551 & 1.191 & & & \\
\hline
\end{tabular}

When Table 7 is examined, it can be observed that the effect size values of the studies carried out at the primary education institutions are greater than other education levels with a value of $g=1,564$. As was put forth earlier, primary education was used without a distinction between primary and secondary school educations since primary education was eight years when the studies were carried out and various studies were applied to the $4^{\text {th }}$ and $5^{\text {th }}$ grades together. On the other hand, when it was examined whether the effect sizes obtained from primary studies differ at a statistically significant level according to the level of education, it was determined that the value of $Q=5,386$ was below the critical value of 5,991 determined in the $\mathrm{X}^{2}$ table at a $95 \%$ level of significance and degrees of freedom of 2 . The fact that the $Q$ value between the groups is lower than the critical value puts forth that the conflict resolution, peace education and peer mediation education programs do not differ at statistically significant levels with regard to the education level applied.

4) Is there a statistically significant difference between the effect sizes of the studies with regard to the type of publication (thesis, article)?

Findings related with whether the studies differ at statistically significant levels according to the type of publication have been given in Table 8:

Table 8. Findings related with the effect size and heterogeneity test according to the publication type

\begin{tabular}{|c|c|c|c|c|c|c|c|}
\hline \multicolumn{2}{|c|}{ Publication Type } & \multirow[b]{2}{*}{$\begin{array}{c}\text { Number of } \\
\text { Studies }\end{array}$} & \multicolumn{2}{|c|}{$\begin{array}{c}95 \text { Confidence Interval }(95 \% \\
C I) \\
\end{array}$} & \multirow[t]{2}{*}{$(d f)$} & \multicolumn{2}{|c|}{ Heterogeneity Test } \\
\hline & Hedge g & & Lower Limit & Upper Limit & & $\begin{array}{c}Q \\
\text { Value }\end{array}$ & $p$ value \\
\hline Master's Degree & 1.443 & 15 & 0.990 & 1.895 & 2 & & \\
\hline Doctorate & 1.132 & 6 & 0.624 & 1.641 & & 8.590 & 0.014 \\
\hline Resarch Study & 0.278 & 2 & -0.359 & 0.915 & & & \\
\hline
\end{tabular}

As can be seen in Table 8 , the highest effect size $(\mathrm{g}=1.443)$ is for master's degree publications. Whereas doctorate thesis publications have an effect size of $g=1.132$. The effect size of two studies published as research study $(\mathrm{g}=0.278)$ were lower in comparison with the others. When it was considered whether the effect sizes varied at a statistically significant level according to publication status or not, it was determined that the value of $Q=8.590$ acquired was greater than the critical value of 5,991 determined in the $X^{2}$ table at a significance level of 
$95 \%$ and degrees of freedom of 2 . These findings indicate that there is a statistically significant difference in the effect sizes of conflict resolution, peace education and peer mediation educations according to the publication type of the studies.

5) Is there a statistically significant difference in the effect sizes of the studies according to the duration of application?

Findings related with whether there is a statistically significant difference between the effect sizes of the studies according to application duration have been given in Table 9.

Table 9. Findings related with the effect size and heterogeneity test according to the duration of application

\begin{tabular}{|c|c|c|c|c|c|c|c|}
\hline \multicolumn{2}{|c|}{ Publication Type } & \multirow[b]{2}{*}{$\begin{array}{c}\text { Number of } \\
\text { Studies }\end{array}$} & \multicolumn{2}{|c|}{95 Confidence Interval $(95 \% C I)$} & \multirow[t]{2}{*}{$(d f)$} & \multicolumn{2}{|c|}{ Heterogeneity Test } \\
\hline & Hedge $g$ & & $\begin{array}{c}\text { Lower } \\
\text { Limit }\end{array}$ & $\begin{array}{l}\text { Upper } \\
\text { Limit }\end{array}$ & & $Q$ Value & $p$ value \\
\hline 1-10 hours & 1.837 & 2 & 0.889 & 2.786 & \multirow{4}{*}{5} & \multirow{5}{*}{7.502} & \multirow{5}{*}{0.112} \\
\hline 11-20 hours & 1.388 & 7 & 0.679 & 2.097 & & & \\
\hline 21-30 hours & 1.894 & 4 & 0.776 & 3.012 & & & \\
\hline 31 hours and above & 0.914 & 9 & 0.421 & 1.407 & & & \\
\hline $\begin{array}{c}\text { Duration } \\
\text { unspecified }\end{array}$ & 0.641 & 1 & 0.014 & 1.267 & & & \\
\hline
\end{tabular}

When Table 9 is examined it can be observed that all effect sizes are in the positive direction and that the effect sizes of studies with application durations of 0-10 hours $(\mathrm{g}=1,837)$ and 21-30 hours $(1,894)$ are greater. However, the difference between the effect sizes is not statistically significant since the $Q=7,502$ value is lower than the critical value of 11,070 determined in the $\mathrm{X}^{2}$ table at a level of significance of $95 \%$ and a degrees of freedom of 5. Accordingly, there is no statistically significant difference with regard to the application duration of the provided education.

6) Is there a statistically significant difference between the effect sizes of the studies according to the type of the application (with selected students or to all students as class based)?

Findings related with whether there is a statistically significant difference between the effect sizes of the studies according to the application type in the studies included have been given in Table 10. The applications have been evaluated in two ways. These have been determined as the trainings the students selected and the studies that the students received as a class.

Table 10. Findings related with the effect size and heterogeneity test according to the type of the application

\begin{tabular}{|c|c|c|c|c|c|c|c|}
\hline \multicolumn{2}{|c|}{ Application Type } & \multicolumn{3}{|c|}{$\begin{array}{c}95 \text { Confidence Interval (\%95 } \\
C I) \\
\end{array}$} & $(d f)$ & \multicolumn{2}{|c|}{ Heterogeneity Test } \\
\hline & Hedge $\mathrm{g}$ & $\begin{array}{c}\text { Number of } \\
\text { Studies }\end{array}$ & Lower Limit & Upper Limit & \multirow{3}{*}{1} & Q Value & $\mathrm{p}$ value \\
\hline Selected & 1.245 & 12 & 0.796 & 1.694 & & \multirow{2}{*}{0.001} & \multirow{2}{*}{0.981} \\
\hline Whole Class & 1.253 & 11 & 0.762 & 1.745 & & & \\
\hline
\end{tabular}

When Table 10 is examined, it can be observed that all the effect sizes are in the positive direction and that the effect size of the applications carried out as a class $(\mathrm{g}=1.253)$ is greater. However, the difference between the effect sizes is not statistically significant since the $Q=0,001$ value is below the critical value of 3.841 determined in the $X^{2}$ table at a level of significance of $95 \%$ and degrees of freedom of 1 . Accordingly, no statistically significant difference has been observed between the effect sizes with regard to the application type.

\section{Discussion}

In this study, the effects of conflict resolution, peace education and peer mediation educations on the conflict resolution skills of the students have been examined by way of meta-analysis method. Accordingly, conflict resolution, peace education and peer mediation education programs have a wide range of effect on the conflict resolution skills of students. Similar results were observed when the study results in the related literature were examined. Johnson and Johnson put forth in a 2001 meta-analysis study that students who received peer 
mediation education used mediation and positive conflict resolution methods more in comparison with students who did not receive this education. Burrell, Zirbel, and Allen (2003) carried out a meta-analysis study evaluating the results of peer mediation educations and applications in education environments in which they put forth that peer mediation reached a significant success with a positive impact on the school environment. Garrard and Lipsey (2007) carried out a meta-analysis study examining the effects of conflict resolution education on antisocial behaviors in which it was determined that this education had a moderate level of impact on antisocial behaviors. Wilson, Lipsey, and Derzon (2003) carried out a meta-analysis study in which they examined the effects of school based intervention programs on aggressive behavior which also included peer mediation education programs. It was put forth in this study that these interventions were quite effective on aggressive behavior. They (Wilson \& Lipsey, 2007) reached similar results in another study in which they expanded their previous studies. Kmitta (1997) carried out a meta-analysis study in which it was emphasized that school based conflict resolution programs have limited but positive effect which changed according to the quality of the conflict resolution education provided. Jones and Kimitta (2000) carried out a comprehensive review study in which they determined that conflict resolution studies had positive impact on the academic success of students, their communication skills, development of interpersonal skills and constructive conflict resolution skills. The results obtained from meta-analyses carried out on conflict resolution, peace education and peer mediation educations in the relevant literature are limited with these studies. When the study results are examined, it can be observed in parallel with the results of this study that conflict resolution, peace education and peer mediation educations result in an increase in the constructive conflict resolution behaviors of students as well as a decrease in destructive, aggressive and antisocial behaviors. It is thought that it is an important result since the participation of children and teenagers in school based conflict resolution, peer mediation and peace education programs will contribute to the students acquiring new and constructive skills.

For the second question of the study, no statistically significant difference was determined between the effect sizes with regard to the education program used in the application. This result is in accordance with the results of studies in the relevant literature (Garrard \& Lipsey, 2007; Lipsey \& Derzon, 2003). This result shows that CRE, $\mathrm{PE}$ and PM education programs with similar attributes but different focus points have similar impact levels.

Even though, a greater effect size was observed in the primary education level within the scope of the third question of the study regarding the examination of the effect sizes according to the education level applied, no statistically significant difference was observed between the primary school, high school and university students. Garrad and Lipsey (2007) determined that conflict educations are more effective in the 14-17 age group, whereas the age group of 5-9 was the group on which it was least effective. Contrary to this, Jones (2004) states that it is more effective in primary schools. Whereas Johnson and Johnson (2001) emphasized parallel to the findings of this study that the effects of the programs do not vary with regard to age. Garrad and Lipsey may have reached such a conclusion since they examined the effects of anti-social behaviors. Because as put forth by the authors, those who benefit most from conflict education are the young people under risk. Jones (2004) has not carried out a meta-analysis and has not been able to put forth a statistically significant difference since the study only carried out a general evaluation of the study results.

When the differentiation between the effect sizes with regard to the type of publication was examined, it can be observed that master's degree theses have the highest effect, whereas research articles have the lowest effect. This result is statistically significant. An examination has not been carried out in similar studies according to publication type. A small number of research articles have been reached in this study. In addition, it can be stated that the greater effect sizes obtained for unpublished theses is a good result for eliminating publication bias.

The fifth question of the study was the examination of the application duration with regard to effect sizes. Even though it was observed that the effect sizes of educations between 1-10 hours and 21-30 hours were observed to be greater, no statistically significant difference was determined with regard to application durations. Garrard and Lipson (2007) observed that a duration ranging between 11-15 hours was more effective. Even though the studies included in this research have different durations, they all have similar effect sizes. The quality of application is more important than what is applied for conflict resolution educations. Hence, one of the best methods of increasing the effectiveness of the programs is to increase the interest towards the elements for application included in the program (Garrard \& Lipson, 2007).

The final question of the study was related with whether effect size changes when the application is carried out with all the students in the class or with a selected group of students. At this point, no difference was observed between the effect sizes according to the application type. Wilson and Lipsey (2007) have reached a similar conclusion. Whereas W. Johnson and R. Johnson (2001) emphasize that the model in which all students participate in peer mediation applications at schools will be more effective in the light of the study they carried 
out. They state that in order to develop the constructive conflict resolution skills at schools, both the school staff and all of the students should have knowledge of these skills. This is important for developing a common understanding in the school. However, it is thought that both application types may be effective for the students to acquire these skills individually.

The limitations of the study can be listed as follows: Only the studies carried out in Turkey have been included in the meta-analysis. It is thought that carrying out a meta-analysis with the inclusion of both national and international studies will be more beneficial as a comprehensive study. In this study, the effects of only CRE, PE and PM educations have been examined from among the programs for preventing violence at schools. It is considered that the examination of the effects of other violence prevention programs with different approaches, social emotional learning programs and school based intervention programs is also important.

In addition, this research has been carried out with a total of 23 studies included in accordance with the inclusion criteria. It should not be neglected that a quite high general effect size has been determined since the number of studies was not too high and that statistically significant results have been acquired from all included studies. In addition, it should be emphasized that studies with different measurement tools (conflict resolution scenarios, peer mediation results etc.) in especially conflict resolution and peer mediation educations have not been included in this study.

It has been concluded in this study that conflict resolution, peace education and peer mediation educations are widely effective on the constructive conflict resolution skills of the students in this study. This result shows that these school based educations may be an important part of the studies for preventing violence at schools. Schools play an important role in supporting scientific developments for raising healthy generations in addition to supporting their social and emotional developments as well (Durlak, Weissberg, Dymnicki, Taylor, \& Schellinger, 2011). Hence, it is thought that applying these education programs at schools and making them a part of school culture are important. It is considered that the systematic and structured use of these education programs that are also included as part of the MEB (Ministry of Education) Violence Action Plan in addition to making them part of the school guidance and psychological counseling programs at schools will make significant contributions to the students. Because, it should be kept in mind that conflict resolution is an indispensable part of prevention. Conflict resolution cannot prevent violence by itself; however it plays an important role in violence prevention studies (Schrumpf, Crawford, \& Bodine, 2007, p. 27). In addition, it is also thought that providing these skills to students from all education levels will contribute to their academic success while also enabling them to acquire new life skills.

In this study, the effects of conflict resolution, peace education and peer mediation educations on conflict resolution skills have been examined. Their effects in decreasing negative behavior (aggressiveness, destructive behavior, disciplinary issues etc.) may be examined in future studies. In addition, empathy is one of the most important skills in conflict resolution, peace education and peer mediation educations. It is not possible to resolve conflicts in a constructive manner without empathy skills (Johnson \& Johnson, 1995; Türnüklü, 2006; Wied, Branje \& Meeus, 2007). Therefore, it is also thought that the effects of these skills on the empathy skill should also be examined. In addition, it is also thought that the effects of other interventions for preventing violence should also be examined and the results should be compared. A comparison has not been made with regard to student gender in this study. The effects of this variable can be examined in future studies. It is thought that studies on the effects of programs applied at schools following the CRE, PE and PM studies will also be beneficial. Because such studies may put forth the differences for students between acquiring these skills and using them in real life.

\section{References}

Akbalık, G. (2001). Çatışma Çözme Ölçeği'nin (Üniversite Öğrencileri Formu) Geçerlik ve Güvenirlik Çalışması. Türk Psikolojik Danışma ve Rehberlik Dergisi, 2(16), 7-13.

Association for Conflict Resolution. (2002). School-based conflict resolution education program standards. Washington, D.C.: Association for Conflict Resolution.

Association for Conflict Resolution. (2007). Standars for school-based peer mediation programs. Washington, D.C.: Association for Conflict Resolution.

Bemak, F., \& Keys, S. (2000). Violent and aggressive youth: intervention and prevention strategies for changing times. Practical skills for counselors. Thousand Oaks, CA: Corwin Press, Inc.

Borenstein, B., Hedges, L. V., Higgins, J. P., \& Rothstein, H. R. (2013). Meta analize giriş. (Çev. S. Dinçer). Ankara: Anı Yayıncılik. 
Breunlin, C. D., Cimmarusti, A.R., Bryant-Edwrads, L. T., \& Hetherington, S. J. (2002). Conflict Resolution Training as an Alternative to Suspension for Violent Behavior. The Journal of Educational Research, 95(6), 349-358. https://doi.org/10.1080/00220670209596609

Bulut, S. (2008). Okullarda görülen öğrenciden öğrenciye yönelik şiddet olaylarının bazı değişkenler açısından arşiv araştırması yöntemiyle incelenmesi. Abant İzzet Baysal Üniversitesi Eğitim Fakültesi Dergisi, 8(2), 23-38.

Burrell, N., Ziber, C. S., \& Allen, M. (2003). Evaluating Peer Mediation Outcomes in Educational Settings: A Meta-Analytic Review. Conflict Resolution Quarterly, 21(1), 7-26. https://doi.org/10.1002/crq.46

Carter, C. C. (2008) Voluntary standards for peace education, Journal of Peace Education, 5(2), 141-155. https://doi.org/10.1080/17400200802264347

Cohen, J. (1968). Weighted kappa: Nominal scale agreement provision for scaled disagreement or partial credit. Psychological Bulletin, 70(4), 213-220. https://doi.org/10.1037/h0026256

Cohen, J. (1988). Statistical power analysis for the behavioral sciences. New Jersey: Lawrence Erlbaum Associates Publishers.

Cohen, R. (2003). Students Helping Students: Peer Mediation. In T. Jones, \& R. Compton (Eds.), Kids Working It Out: Stories and Strategies for Making Peace in Our Schools. San Francisco: Jossey-Bass.

Dinçer, S. (2014). Eğitim bilimlerinde uygulamalı meta-analiz. Pegem:Ankara.

Droisy, R. H., \& Gaudron, Z. C. (2003). Interpersonal conflict resolution strategies in children: A father-child co-construction. Europen Journal of Psychology of Education, 18(2), 157-169. https://doi.org/10.1007/bf03173482

Durlak, J. A. (1995). Reading and Understanding Multivariate Statistics. Washington DC: American Psychological Association.

Durlak, J. A., Weissberg, R. P., Dymnicki, A. B., Taylor, R. D., \& Schellinger, K. B. (2011). The impact of enhancing students' social and emotional learning: A meta-analysis of school-based universal interventions. Child development, 82(1), 405-432. https://doi.org/10.1111/j.1467-8624.2010.01564.x

Garrard, W. M., \& Lipsey, M. W. (2007). Conflict resolution education and antisocial behavior in US schools: A meta-analysis. Conflict Resolution Quarterly, 25(1), 9-38. https://doi.org/10.1002/crq.188

Glass, V. G. (1976). Primary, secondary, and meta-analysis of research educational researcher. American Educational Research Association Stable, 5(10), 3-8. https://doi.org/10.3102/0013189x005010003

Hart, J., \& Gunty, M. (1997). The Impact of A Peer Mediation Program On An Elementary School Environment. Peace\&Change, 22(1), 76-92. https://doi.org/10.1111/0149-0508.00038

Johnson, D. W., \& Johnson, R. T. (2006). Peace education for consensual peace: the essential role of conflict resolution. Journal of Peace Education, 3(2), 147-174. https://doi.org/10.1080/17400200600874792

Johnson, W. D., \& Johnson, R. (2001). Teaching Students to be peacemakers: A Meta-Analysis. Research Reports. The Annual Meeting of the American Educational Research Association (Seattle WA. 10-14 April 2001). https://doi.org/10.3102/0013189x029008032

Johnson, W. D., \& Johnson, T. R. (1995). Teaching Students To Be Peacemakers. Edina, MN: Interaction Book Co.

Jones, S. T. (2004). Conflict Resolution Education: The Field, The Findings and The Future. Conflict Resolution Quarterly, 22(1-2), 233-276. https://doi.org/10.1002/crq.100

Jones, T. S., \& Kmitta, D. (2000). Does It Work? The Case for Conflict Education in Our Nation's Schools. Washington, D.C.: Conflict Resolution Education Network.

Kansızoğlu, H. S. (2017). Grafik örgütleyicilerin dil öğretmen ve öğrenme alanlarındaki başarıya etkisi: Bir meta analiz çalışması. Eğitim ve Bilim, 42(191), 139-164. http://dx.doi.org/10.15390/EB.2017.6777

Kimitta, D. M. (1997). Peaceful posstblltties: three years of evaluative research of school based conflict resolution programs (Unpublished doctoral thesis). University of Cincinnati the College of Education.

Kınay, E. (2012). Üniversiteye girişs sınavlarının yordama geçerliği çalışmalarının meta analizi. Yayınlanmamış Yüksek Lisans Tezi. Ankara Üniversitesi Eğitim Bilimleri Enstitüsü, Ankara.

Koruklu (Öner), N. (1998). Arabuluculuk eğitiminin ilköğretim düzeyindeki bir grup öğrencinin çatışma çözme davranışlarına etkisinin incelenmesi. Yayınlanmamış Yüksek Lisans Tezi. Ankara Üniversitesi Sosyal 
Bilimler Enstitüsü.Ankara.

Küçükönder, H. (2007). Meta analiz ve tarımsal uygulamalar. Yüksek Lisans Tezi, Kahramanmaraş: Kahramanmaraş Sütçü İmam Üniversitesi Fen Bilimleri Enstitüsü.

Lam, R. W., \& Kennedy, S. H. (2005). Using meta analysis to evaluate evidence: Practical tips and traps. Canadian Journal of Psychiatry, 50, 167-174. https://doi.org/10.1177/070674370505000306

Lane-Garon, S. P. (2000). Practicing peace: the impact of a school-based conflict resolution program on elementary students. Peace \& Change, 25(4), 467- 482. https://doi.org/10.1111/0149-0508.00169

Milli Eğitim Bakanlığı Özel Eğitim Rehberlik ve Danışma Hizmetleri Genel Müdürlüğü. (2006). 24/03/2006 tarihli ve 1342 sayll, 2006/26 numarall ve "Okullarda Şiddetin Önlenmesi” konulu Genelgesi. Retrieved from https://orgm.meb.gov.tr/meb_iys_dosyalar/2015_10/08101631_okullardaiddetinnlenmesigenelgesi.pdf

Milli Eğitim Bakanlı̆̆ı. (2006). Eğitim Ortamlarında Şiddetin Önlenmesi ve Azaltılması Strateji ve Eylem Planı (2006-2011+). Ankara: Milli Eğitim Bakanlığı.

Öğülmüş, S. (2006). Okullarda şiddet ve alınabilecek önlemler. Eğitime Baklş, 2(7), 16-24.

PISA. (2015). Öğrencilerin iyi olma hali raporu. Retrieved from https://tedmem.org/mem-notlari/degerlendirme/ pisa-2015-ogrencilerin-iyi-olma-hali 01/08/2017 tarihinde indirildi.

Sağkal, S. A. (2015). Barış eğitimi programının dokuzuncu sınıf öğrencilerinin şiddete yönelik tutumları, sosyal problem çözme becerileri ve sınıf iklimi üzerindeki etkisi. Yayınlanmamış Doktora Tezi. Dokuz Eylül Üniversitesi Eğitim Bilimleri Enstitüsü, İzmir.

Sarı, S. (2005). Ilköğretim 5.sınıf ögrencilerine çatişma çözümü becerilerinin kazandırılmasında akademik çelişki, değer çizgisi ve güdümlü tartışma yöntemlerinin etkisi. Yayınlanmamış Yüksek Lisans Tezi. Çukurova Üiversitesi Sosyal Bilimler Enstitüsü. Adana.

Schrumpf, F., Crawford, D. K., \& Bodine, R. J. (2007). Okulda çatışma çözme ve akran arabuluculuk. Ankara: İmge.

Smith, W. S., Daunic, P. A., Miller, D. M., \& Robinson, R. T. (2002). Conflict resolution and peer mediation in middle schools: extending the process and outcome knowledge base. The Journal of Social Psychology, 142(5), 567- 586. https://doi.org/10.1080/00224540209603919

Sommers, M. (2003). Peace Education: Opportunities and Challenges. Presentation at essential role of conflict resolution. Journal of Peace Education, 3(2), 147-174.

Sun, S. (2011). Meta-analysis of Cohen's kappa. Health Serv Outcomes Res Method, 11, $145-163$. https://doi.org/10.1007/s10742-011-0077-3

Taştan, N. (2004). Çatışma çözme ve akran arabuluculuğu eğitimi programlarının ilköğretim altıncı sınıf öğrencilerinin çatışma çözme ve akran arabuluculuğu becerilerine etkisi. Yayınlanmamış Doktora Tezi. Ankara Üniversitesi Eğitim Bilimleri Enstitüsü.Ankara.

TBMM Araştırma Komisyonu (2007). Çocuklarda ve gençlerde artan şiddet eğilimi ile okullarda meydana gelen olayların araştırılarak alınması gereken önlemlerin belirlenmesi amacıyla kurulan meclis araştırma komisyonu raporu. Türkiye Büyük Millet Meclisi Tutanak Dergisi, 160, 464-465.

Thalheimer, W., \& Cook, S. (2002). How to calculate effect size from published research: A simplified spreadsheet. Retrieved from http://worklearning. com/effect_sizes.htm

Türk, F., \& Cihangiroğlu, Ü. (2017). Uygulamaya Dayalı Psikolojik Danışma ve Rehberlik Lisansüstü Tezlerinin Tematik ve Metodolojik Olarak Incelenmesi. 26. Uluslararası Eğitim Bilimleri Kongresi, 20-23 Nisan, Antalya.

Türnüklü, A. (2006). Sınıf ve Okul Disiplinine Çăgdaş Bir Yaklaşım: Onarıcı Disiplin. Ankara: Ekinoks

Üstün, U., \& Eryılmaz, A. (2014). Etkili araştırma sentezleri yapabilmek için bir araştırma yöntemi: Meta-Analiz. Eğitim ve Bilim, 39(174), 1-32. https://doi.org/10.15390/eb.2014.3379

Wied, M., Branje, S. T., \& Meeus, W. H. J. (2007). Empathy and Conflict Resolution in Friendship Relations Among Adolescents. Aggressive Behavior, 33, 48-55. https://doi.org/10.1002/ab.20166

Wilson, S. J., \& Lipsey, M. W. (2007). School-based interventions for aggressive and disruptive behavior: Update of a meta-analysis. American journal of preventive medicine, 33(2), S130-S143. https://doi.org/10.1016/j.amepre.2007.04.011 
Wilson, S. J., Lipsey, M. W., \& Derzon, J. H. (2003). The effects of school-based intervention programs on aggressive behavior: a meta-analysis. Journal of Consulting and Clinical Psychology, 71(1), 136-149. https://doi.org/10.1037//0022-006x.71.1.136

\section{Appendix A}

\section{Studies Included in the Meta-Analysis}

Arslan, E. (2014). 7. Sınıf öğrencilerine uygulanan bir akran arabuluculuk eğitiminin akran arabulucuların çatışma çözme becerilerine olan etkisinin incelenmesi. Yayınlanmamış Yüksek Lisans Tezi. Çukurova Üniversitesi Sosyal Bilimler Enstitüsü, Adana.

Ateş, N. (2014). Çatışma çözme eğitiminin 6. Sınıf öğrencilerinin çatışma çözme becerileri ve özsaygı düzeylerine etkisi. Yayınlanmamış Yüksek Lisans Tezi. Haliç Üniversitesi Sosyal Bilimler Enstitüsü, İstanbul.

Çavuş Kasik, N. (2012). Çatışma çözme ve akran arabuluculuğu eğitim programının benlik saygısı ve çatışma çözme becerilerine etkisi. Yayınlanmamış Yüksek Lisans Tezi.Ondokuz Mayıs Üniversitesi Eğitim Bilimleri Enstitüsü, Samsun.

Çiçekoğlu, P. (2014). Yetiştirme yurdunda kalan ergenlere verilen çatışma yönetimi programının değerlendirilmesi.Yayınlanmamış Doktora Tezi. Marmara Üniversitesi Sağlık Bilimleri Enstitüsü, İstanbul.

Coşkuner, E. (2008). Barış eğitimi programının öğrenci şiddeti üzerindeki etkilerinin incelenmesi. Yayınlanmamış Yüksek Lisans Tezi. Dokuz Eylül Üniversitesi Eğitim Bilimleri Enstitüsü, İzmir.

Damirchi, S., Bilge, F. (2014). Barış eğitimi programının yedinci sınıf öğrencilerinin çatışma çözme ve iletişim becerilerine etkisi. Eğitim ve Bilim. 39 (175), 309-318.

Ergül, H. (2008). Müzakere (problem çözme) ve arabuluculuk" eğitim programının ortaöğretim 9. Sınıf öğrencilerinin çatışma çözüm becerileri, atılganlık becerileri ile saldırganlık düzeyleri üzerindeki etkisinin incelenmesi. Yayınlanmamış Yüksek Lisans Tezi. Dokuz Eylül Üniversitesi Eğitim Bilimleri Enstitüsü, İzmir.

Gülkokan, Y. (2011). “Akran arabuluculuk eğitiminin” ilköğretim öğrenci anlaşmazlıkları üzerindeki etkisinin incelenmesi. Yayınlanmamış Yüksek Lisans Tezi. Dokuz Eylül Üniversitesi Eğitim Bilimleri Enstitüsü, İzmir.

Gündoğdu, R. (2009). Yaratıcı drama temelli çatışma çözme programının ergenlerde öfke, saldırganlık ve çatışma çözme becerisine etkisi. Yayınlanmamış Doktora Tezi. Selçuk Üniversitesi Sosyal Bilimler Enstitüsü, Konya.

Kaya, B. (2013). Barış eğitimi programı’nın kültürlerarası yeterlilik ve çatışma çözme stratejilerine etkisi. Yayınlanmamış Yüksek Lisans Tezi. Kocaeli Üniversitesi Sosyal Bilimler Enstitüsü, Kocaeli.

Kuş, M. (2007). Çatışma çözümü eğitimi programının Anadolu lisesi düzeyindeki bir grup öğrencinin çatışma çözme davranışlarına etkisinin incelenmesi. Yayınlanmamış Yüksek Lisans Tezi. Yıldız Teknik Üniversitesi Sosyal Bilimler Enstitüsü, İstanbul.

Kutlu, A. (2016). Çatışma Çözme Psikoeğitim Programının Ortaokul Öğrencilerinin, Çatışma Çözüm Becerileri, Sürekli Öfke ve Öfke İfade Tarzları Üzerindeki Etkisi. Yayınlanmamış Yüksek Lisans Tezi. Mevlana Üniversitesi Sosyal Bilimler Enstitüsü, Konya.

Mutluoğlu, S., Serin, O. (2012). Çatışma çözme eğitim programının ilkokul 5. Sınıf öğrencilerinin çatışma çözme becerilerine etkisi. Turkish International Journal of Special Education and Guidance \& Counceling, $1(1), 25-34$.

Öner Koruklu, N. (2003). Arabuluculuk eğitiminin iletişim ve çatışma çözme becerisine etkisi: Bir grup üniversite öğrencisi üzerinde çalışma. Yayınlanmamış Doktora Tezi. Dokuz Eylül Üniversitesi Eğitim Bilimleri Enstitüsü, İzmir.

Şahin Altun, Ö. (2011). Çatışma çözümü eğitiminin hemşirelik öğrencilerinin çatışma çözüm becerisine etkisi. Yayınlanmamış Doktora Tezi. Atatürk Üniversitesi Sağlık Bilimleri Enstitüsü, Erzurum.

Şevkin, B. (2008). Müzakere (problem çözme) ve arabuluculuk eğitim programının ilköğretim 4.-5. Sınıf öğrencilerinin çatışma çözüm stilleri ve saldırganlık eğilimleri üzerindeki etkilerinin incelenmesi. Yayınlanmamış Yüksek Lisans Tezi. Dokuz Eylül Üniversitesi Eğitim Bilimleri Enstitüsü, İzmir.

Sünbül, D. (2008). Müzakere (problem çözme) ve arabuluculuk eğitim programının ortaöğretim 9. sınıf 
öğrencilerinin çatışma çözme becerileri, öfke kontrolü ile özsaygı düzeyleri üzerindeki etkisinin incelenmesi. Yayınlanmamış Yüksek Lisans Tezi. Dokuz Eylül Üniversitesi Eğitim Bilimleri Enstitüsü, İzmir.

Tapan, Ç. (2006). Barış eğitim programının öğrencilerin çatışma çözme becerileri üzerindeki etkisinin incelenmesi. Yayınlanmamış Yüksek Lisans Tezi. Dokuz Eylül Üniversitesi Eğitim Bilimleri Enstitüsü, İzmir.

Taştan, N. (2004). Çatışma çözme ve akran arabuluculuğu eğitimi programlarının ilköğretim altıncı sınıf öğrencilerinin çatışma çözme ve akran arabuluculuğu becerilerine etkisi. Yayınlanmamış Doktora Tezi. Ankara Üniversitesi Eğitim Bilimleri Enstitüsü, Ankara.

Türk, F. (2008). Müzakere (Problem Çözme) ve Arabuluculuk Eğitim Programının İlköğretim 4. ve 5. Sinıf Öğrencilerinin Çatışma Çözme Becerileri Üzerindeki Etkisinin İncelenmesi. Yayınlanmamış Yüksek Lisans Tezi. Dokuz Eylül Üniversitesi Eğitim Bilimleri Enstitüsü, İzmir.

Türk, F. (2013). Akran Arabuluculuk Eğitiminin Lise Öğrencilerinin Arabuluculuk Becerilerine Etkisinin İncelenmesi. Yayınlanmamış Doktora Tezi. Dokuz Eylül Üniversitesi Eğitim Bilimleri Enstitüsü, İzmir.

Uysal, Z. (2006). Çatışma çözme eğitim programının ortaöğretim dokuzuncu sınıf düzeyindeki öğrencilerin çatışma çözme becerilerine etkisi. Yayınlanmamış Yüksek Lisans Tezi. Çukurova Üniversitesi Sosyal Bilimler Enstitüsü, Adana.

Zengin, F. (2008). Müzakere (problem çözme) ve arabuluculuk eğitim programının ilköğretim 4.-5. Sınıf öğrencilerinin çatı̧̧ma çözüm stilleri ve atılganlık becerileri üzerindeki etkilerinin incelenmesi. Yayınlanmamış Yüksek Lisans Tezi. Dokuz Eylül Üniversitesi Eğitim Bilimleri Enstitüsü, İzmir.

\section{Copyrights}

Copyright for this article is retained by the author(s), with first publication rights granted to the journal.

This is an open-access article distributed under the terms and conditions of the Creative Commons Attribution license (http://creativecommons.org/licenses/by/4.0/). 